TITLE:

\title{
New canine spinal cord injury model free from laminectomy( Abstract_要旨)
}

\author{
$\operatorname{AUTHOR}(\mathrm{S})$ : \\ Fukuda, Seijun
}

\section{CITATION:}

Fukuda, Seijun. New canine spinal cord injury model free from laminectomy. 京都大学, 2006, 博士(医学)

\section{ISSUE DATE:}

2006-05-23

URL:

http://hdl.handle.net/2433/135626

RIGHT: 

氏
名

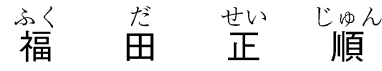
学位 (専攻分野)
博士 (医 学)
学位記番号
医 博 第 3006 号
学位授与の日付
平成 18 年 5 月 23 日
学位授与の要件
学位規則第 4 条第 1 項該当
研究科・尃攻
医学研究科外科系専攻
学位論文題目
New Canine Spinal Cord Injury Model Free From Laminectomy
(イヌに適用した椎弓切除術を必要としない脊䯣損傷モデル)
論文調查委員
(主 查) 教 村 孝志
教 授 橋 本 信 夫
教 授 真 鍋 俊 明

\section{論文 内容の要旨}

本研究の目的は脊髄損傷の治療法の有効性を評価するための脊髄損傷モデルの確立することである。このモデルは臨床に 即したものが望ましい。しかしこれまでのモデルは椎弓切除を伴う脊髄損傷であったため, イヌなどの大型動物にそのまま で適用するには問題があった。まず閉鎖空間でないため，2次損傷の進展が異なるということである。また再生過程での周 囲組織の影響も無視できない。そこで新たなバルーンを用いたイ又脊髄損傷モデルが考案された。この方法では椎弓切除術 は不要である。またイヌなどの大型動物モデルには臨床に用いる MRI や血管造影の装置がそのまま適用可能であるため,

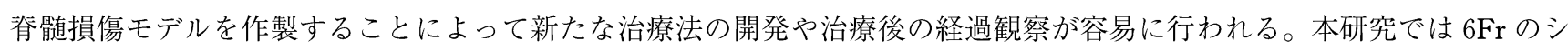
リコンバルーンカテーテル（三矢メディカル（株））を使用した。イ又の椎間孔からカテーテルを硬膜外の脊椎腔内に挿入 した。カテーテルの先を第一腰椎まで進めて，バルーンを膨らませ，10分間保持して圧迫損傷させた。6匹のイヌでは $1.5 \mathrm{ml}$ の生食で圧迫損傷を加え, 3 匹のイヌでは $1.0 \mathrm{ml}$ の生食で圧迫損傷を加えた。術後の歩行機能は Basso, Beattie, Bresnahan（BBB）による21点スコアを用いて評価した。術直後よりすべてのイヌで麻瘦が生じた。術後 1 週間の評価でも $1.5 \mathrm{ml}$ で圧迫した 6 匹のイヌでは両下肢の動きはまったく認められなかった。BBB スコアは 0 点だった。一方 $1.0 \mathrm{ml} て ゙$ 圧 迫した 3 匹のイヌでは下肢の動きが多少認められた。1.5ml のモデルではそれ以降 6 ケ月間も両下肢の自発的な動きは観察 できず, BBB スコアは 1 点以下だった。脊䯣の変化は定期的に MR 撮像を行って評価した。手術直後の T2 強調の MRIで は圧迫部位の脊髄に高信号が認められた。同部位は 3 ケ月以降低信号を呈した。また中枢側㧍よび末梢側への病変の広がり が確認でき，脊髄損傷に二次損傷が示唆された。この変化はこのモデルが臨床のモデルに近いことを意味する。6ヶ月後の 組織標本に HE 染色, Luxol Fast Blue 染色，免疫染色を実施して顕微鏡下に観察した。脊䯣を損傷した圧迫中心でMasson trichrome 染色で青く染まる瘷痕形成を認められた。このことから痛痕には多量のコラーゲンが含まれることが示唆さ れた。同時に硬膜の肥厚も認めた。組織標本で比較するとコントロールの約 2 倍の厚みがあった。中枢側㧍よび末梢側に進 展する空洞形成が観察され，空洞の周辺には圧迫損傷で変性した組織を会食する大小球形のマクロファージ様の細胞が見ら れた。加えて損傷の中枢側では軸索の浮腫性変化とグリアの増生を認めた。この定量的評価には Scionimage Beta4.0.2 ソ フトゥエアが用いられた。上述のように椎弓切除術を必要としない春髄損傷作製方法を用いて $1.5 \mathrm{ml}$ のバルーン損傷によ り，不可逆的なイヌの脊髄損傷モデルを作製し，人間の典型的な臨床に近い像を得ることができた。

\section{論文 審査の結果 の 要旨}

脊髄損傷に対する治療法を開発する上で, 基礎となる動物モデルを確立することが重要である。従来の動物モデルは脊髄 損傷の作製に先立って Laminectomy（椎弓切除術）を行っていた。Laminectomy は実験動物に大きな侵襲を与え，さらに 脊柱管内が閉鎖空間でなくなるため，2 次損傷の進展が異なる欠点がある。申請者は Laminectomyを行わずに脊䯣損傷モ デルを作製することを大型動物としてのイヌを用いて検討した。 
第 3 及び第 4 腰椎の椎間孔から脊柱管内に上行性に挿入し, 第1腰椎レベルに先端を留置したバルーンに生理的食塩水 $1.5 \mathrm{ml}$ を注入して硬膜外から脊髄を圧迫損傷させた。脊䯣の損傷度は運動機能評価，脊髄誘発電位，MRI，組織検査によ り確認した。結果として, 用いた 6 頭のイヌでは損傷後 6 ケ月時点でも両下肢の運動は全く認められなかった。損傷直後と 3 ヶ月後の MRI を比較すると, 病変は中枢側および末梢側へ拡大しており，一次損傷に引き続いて二次損傷が発生してい ることが確認され，作製したイ又脊䯣損傷の病態が，ヒト脊髄損傷の病態と類似したものであることが確認された。このモ デルは寿命が1年程度の彗歯類モデルではできなかった長期の評価や，ヒト用の MRI 装置や血管造影装置を用いたintervention 治療が可能であり，新規春髄損傷の治療法の開発に寄与するところが多い。

したがって，本論文は博士（医学）の学位論文として価值あるものと認める。

なお，本学位授与申請者は，平成18年 3 月13日実施の論文内容とそれに関連した試問を受け，合格と認められたものであ る。 